\title{
2. Diary of an Election
}

\section{Marian Simms}

That the 2010 election was unusual is not in dispute. The 'sacking' of a prime minister during an election year, the decision to go to the polls only 22 days after the leadership change, a controversial campaign marred by serial leaks from within the government, a change in the campaign slogan and strategy by the government, a low-key campaign launch, and a series of ad-hoc decisions regarding debates and community forums - these were some of its defining features. Moreover, the election result was so close as to create a further 17 days of indecision and a total of 24 days before the formal creation of a minority government under Julia Gillard's leadership.

This chapter argues that drawing upon New Zealand's experience, the term 'interregnum' captures the nature of the period. Interregnum refers to the time in the lead-up to the election, the campaign itself, the declaration of the result and the swearing in of the government (see Simms 2011). It incorporates a caretaker period and assumes that there could be a delay in forming government. The interregnum idea also includes the immediate pre-election period. It deemphasises the incumbency factor, and includes the suggestion of tentativeness and searching for new rules.

In Australian federal politics, discussions about the 'caretaker' issues normally refer to the campaign period itself, and the brief period between the announcement of the election and the dissolution of the Parliament. The idea of the interregnum moves away from the traditional idea of the campaign 'map' where the Prime Minister calls an election, based on a well-developed strategy, and implements this via a well-choreographed sequence of events. Since 1993, Australian prime ministers have announced their intention to call an election outside the Parliament, and while the Parliament is not in session. The writs are issued and the nation moves into campaign mode. The map includes a leaders' debate and well-timed policy launches, culminating - usually in week threewith the formal party launches. In the final week, the Leader of the Opposition and the Prime Minister separately address the National Press Club.

This caretaker election commenced with the Prime Minister deliberately positioning herself in caretaker mode, by refusing to move into the Lodge and by indicating at the outset that an election would need to be held to vindicate her position, and to provide a mandate (see Table 2.1). 
Julia 2010: The caretaker election

Table 2.1 Labor's Early Interregnum, June-July 2010

\begin{tabular}{|l|l|l|}
\hline 24 June 2010 & $\begin{array}{l}\text { Julia Gillard replaces Kevin Rudd as } \\
\text { ALP leader }\end{array}$ & $\begin{array}{l}\text { Government 'losing its way under } \\
\text { Rudd', cancels mining tax ads and } \\
\text { reviewspolicies on asylum-seekers } \\
\text { and climate change } \\
\text { Gillard indicates she will not move } \\
\text { into the Lodge unless elected }\end{array}$ \\
\hline 6 July & $\begin{array}{l}\text { Julia Gillard announces the 'Timor } \\
\text { solution' of an offshore processing } \\
\text { centre in the region in response to } \\
\text { questions about 'boat people' in } \\
\text { Penrith }\end{array}$ & $\begin{array}{l}\text { See The Age [Insight], 10 July } \\
\text { 2010 }\end{array}$ \\
\hline 7 July & $\begin{array}{l}\text { Julia Gillard visits border-patrol } \\
\text { vessels in Darwin accompanied by } \\
\text { David Bradbury, ALP MP for Lindsay } \\
\text { in Sydney's west }\end{array}$ & $\begin{array}{l}\text { See The Age [Insight], 10 July } \\
2010\end{array}$ \\
\hline 15 July 2010 & $\begin{array}{l}\text { Julia Gillard at the Press Club } \\
\text { challenged by Laurie Oakes' question } \\
\text { regarding the Rudd deal to step down }\end{array}$ & Leak No. 1 \\
\hline
\end{tabular}

The interregnum can be divided into four stages: the first, before the election was called (24 June - 16 July); the second, the initial part of the campaign after the election was called-dominated by crises, leaks and the drop in the opinion polls (17 July - 28-31 July); the third, marked by the emergence of the 'real' Julia and ending with the election (1 August - 21 August); and the fourth and final stage, where the crafting of a majority occurred (22 August - 14 September). The middle, second and third periods - the campaign-are potentially divisible in a number of ways. The sharp drop in the ALP's opinion poll results (31 July) and the emergence of the so-called 'new' or 'real' Julia are defining events that occurred at about the same time. Julia Gillard's well-crafted response to Leak No. 4 (see Table 2.2) was on 28 July. Hence, stage two is from 17 to 31 July; and stage three is 1 August - 21 August.

The focus here is on the second and third stages of the interregnum; and the first and fourth stages are briefly outlined in Tables 2.1 and 2.3, and are dealt with by other chapters in this volume (Chapters 3 and 28). This chapter relies on close analysis of New Limited's Sky TV News (Foxtel and Austar) programs, including its interactive news features and blogs; ABC News, 7.30 Report and Lateline; and the Sydney and Melbourne newspapers. ${ }^{1}$ As in 2007, in 2010, the role of Sky News provided an attractive tool for campaigning, a tool for commentators and a challenge for campaigners. Whilst the audience size was limited, Sky 24-Hour News provided a greater immediacy and allowed a dialogue between the campaigners that could be picked up by other players and media outlets, and thus set the agenda. For example, Julia Gillard's interview with David Speers on the first day of the campaign tackled climate change, and, while

1 Sky News transcripts are available for The Nation, Australian Agenda and Sky Business Channel's The Perrett Report. 
Gillard indicated broad support or even commitment to a price on carbon, she expressed concern about the lack of community-based consensus on the issue, and suggested that it would be essential in order to forge a workable policy (Sky News, 17 July 2010). Later in the campaign, Kerry O'Brien quoted from George Brandis's interview on Sky News (we 'cannot be certain when the budget will be back in surplus') to ask Tony Abbott for 'clarification' on the Coalition's fiscal policies (7.30 Report, ABC TV, 17 August 2010).

\section{Stage Two}

On Saturday, 17 July, Julia Gillard flew to Canberra to seek the dissolution of the Parliament, and then gave a press conference, announcing the election date of 21 August and outlining her rationale (see Table 2.1). This speech (Gillard 2010d) built upon the economic reform agenda and 'moving forward' theme of the 15 July Press Club speech (Gillard 2010c); the 'refugees' and 'sustainability' concerns of the Lowy Institute speech of 6 July (Gillard 2010b); and the political legitimacy or 'mandate' theme of her press conference of 24 June (Gillard 2010a).

Tony Abbott's response was immediate, stating that, if elected, he would: 'stand up for Australia', 'stop new taxes', 'stop the boats' and 'stop the waste'. He also announced a three-year moratorium on industrial relations and that he would not be changing the current law; yet he remained a 'conviction politician'.

The first fumble of the campaign occurred in a Sky News interview with Eric Abetz on 17 July, with him saying that industrial relations could be 'tweaked' through ministerial regulations, without recourse to amending the legislation.

From the outset, the electronic and print media commentary focused on the geography of the campaign, and the precise mapping of the leaders' movements became a feature of the commentary. A favourite metaphor was 'battleground' applied to the States (John Roskam, Sky TV, 17 July 2010) and 'seats' (Bruce Hawker, Sky TV, 17 July 2010). This early focus on the local, regional and State levels was significant, for it marked a shift away from the overarching sense of a presidential-style generic national campaign. Both leaders spent time in Queensland in the first few days, and then in the western suburbs of Sydney. 
Table 2.2 Key Dates in the 2010 Election Campaign

\begin{tabular}{|c|c|c|c|}
\hline Date & Event & Comments & $\begin{array}{l}\text { Media coverage } \\
\text { highlights }\end{array}$ \\
\hline 17 July & $\begin{array}{l}\text { Election called for } 21 \\
\text { August }\end{array}$ & & \\
\hline 19 July & $\begin{array}{l}\text { Writs issued for the } \\
\text { election }\end{array}$ & & \\
\hline 19 July & $\begin{array}{l}\text { Rolls close for new } \\
\text { electors }\end{array}$ & & \\
\hline 19 July & $\begin{array}{l}\text { Tony Abbott's comment: } \\
\text { WorkChoices is 'dead, } \\
\text { buried and cremated' }\end{array}$ & & \\
\hline 22 July & $\begin{array}{l}\text { Rolls close for electors } \\
\text { updating details }\end{array}$ & & \\
\hline 22 July & $\begin{array}{l}\text { Campaigning suspended } \\
\text { for digger's funeral }\end{array}$ & & \\
\hline 23 July & $\begin{array}{l}\text { Kevin Rudd denies ignoring } \\
\text { security concerns by } \\
\text { sending chief of staff to } \\
\text { National Security meetings }\end{array}$ & $\begin{array}{l}\text { Leak No. } 2 \text { via the } \\
\text { ABC }\end{array}$ & \\
\hline 23 July & $\begin{array}{l}\text { Julia Gillard announces } \\
\text { policy of citizens' assembly } \\
\text { on climate change }\end{array}$ & & \\
\hline 24 July & $\begin{array}{l}\text { Gillard announces second- } \\
\text { hand car trade-in discount }\end{array}$ & & \\
\hline 24 July & $\begin{array}{l}\text { GetUp!'s High Court } \\
\text { challenge to early roll } \\
\text { closure }\end{array}$ & & \\
\hline 25 July & The leaders' debate & $\begin{array}{l}\text { The 'worm' } \\
\text { supports Gillard, } \\
\text { but most } \\
\text { commentators } \\
\text { on Sky and Nine } \\
\text { see Abbott as the } \\
\text { better performer }\end{array}$ & $\begin{array}{l}\text { News Limited press } \\
\text { focus on Gillard's 'ear } \\
\text { lobes' }\end{array}$ \\
\hline 26 July & $\begin{array}{l}\text { Abbott's first } 7.30 \text { Report } \\
\text { interview }\end{array}$ & & \\
\hline 27 July & $\begin{array}{l}\text { Cabinet leak story by } \\
\text { Laurie Oakes (Nine } \\
\text { News) and Peter Hartcher } \\
\text { (Sydney Morning Herald) }\end{array}$ & $\begin{array}{l}\text { That Gillard } \\
\text { opposed pension } \\
\text { increases and } \\
\text { the introduction } \\
\text { of paid parental } \\
\text { leave in Cabinet } \\
\text { discussions } \\
\text { Leak No. } 3\end{array}$ & $\begin{array}{l}\text { The Australian } \\
\text { promotes Newspoll } \\
\text { results: 'Labor's core } \\
\text { intact' }\end{array}$ \\
\hline 28 July & $\begin{array}{l}\text { Gillard's rebuttal of the } \\
\text { claim, suggesting people } \\
\text { should examine her record }\end{array}$ & $\begin{array}{l}\text { Previously, Gillard } \\
\text { had cited Cabinet } \\
\text { confidentiality in } \\
\text { neither confirming } \\
\text { nor denying the } \\
\text { claim }\end{array}$ & $\begin{array}{l}\text { Peter Hartcher's } \\
\text { comment: 'prime } \\
\text { ministerial image is } \\
\text { cracking and peeling' } \\
\text { David Speers: Gillard } \\
\text { was 'impressive' }\end{array}$ \\
\hline
\end{tabular}




\begin{tabular}{|c|c|c|c|}
\hline Date & Event & Comments & $\begin{array}{l}\text { Media coverage } \\
\text { highlights }\end{array}$ \\
\hline 29 July & $\begin{array}{l}\text { Belinda Neal ends } \\
\text { speculation she will } \\
\text { contest Robertson as an } \\
\text { Independent }\end{array}$ & $\begin{array}{l}\text { Preselection won } \\
\text { by Deborah O'Neill } \\
\text { in March } 2010\end{array}$ & \\
\hline 29 July & $\begin{array}{l}\text { Kevin Rudd admitted to } \\
\text { hospital }\end{array}$ & & \\
\hline 30 July & $\begin{array}{l}\text { Spokesperson announces } \\
\text { Kevin Rudd will resume } \\
\text { campaigning next week }\end{array}$ & & \\
\hline 31 July & $\begin{array}{l}\text { Another leak: that Gillard } \\
\text { sent former security } \\
\text { guard to National Security } \\
\text { meetings }\end{array}$ & $\begin{array}{l}\text { Leak No. } 4 \text { via } \\
\text { The Australian }\end{array}$ & $\begin{array}{l}\text { The Australian } \\
\text { headline: 'Bodyguard } \\
\text { deputising for Gillard' } \\
\text { Dennis Shanahan notes } \\
\text { that the 'leaks are } \\
\text { working for Abbott' }\end{array}$ \\
\hline 31 July & $\begin{array}{l}\text { Labor loses lead in Nielsen } \\
\text { poll for two-party preferred } \\
\text { vote }\end{array}$ & & \\
\hline 1 August & Greens policy launch & & \\
\hline 2 August & The 'real Julia' appears & & \\
\hline 3 August & No interest rate rise & & \\
\hline 4 August & $\begin{array}{l}\text { Labor loses } 6 \% \text { in two- } \\
\text { party preferred vote in one } \\
\text { week, and } 7 \% \text { in prime } \\
\text { ministerial approval rating } \\
\text { according to Newspoll }\end{array}$ & & $\begin{array}{l}\text { The Australian } \\
\text { promotes Newspoll } \\
\text { results (Qld, NSW } \\
\text { voters turn on Labor) } \\
\text { The Age criticises } \\
\text { Abbott's parental-leave } \\
\text { plans } \\
\text { Herald Sun praises } \\
\text { Abbott's 'gold-collar } \\
\text { workers' scheme' to } \\
\text { employ older workers }\end{array}$ \\
\hline 6 August & $\begin{array}{l}\text { High Court decision to } \\
\text { support GetUp! challenge } \\
\text { to Howard electoral law }\end{array}$ & & \\
\hline 6 August & $\begin{array}{l}\text { Release of Orgill (Interim) } \\
\text { Report on BER scheme }\end{array}$ & $\begin{array}{l}\text { Finds programs } \\
\text { meeting overall } \\
\text { objectives }\end{array}$ & $\begin{array}{l}\text { Negative media in } \\
\text { The Australian, Sydney } \\
\text { Morning Herald around } \\
\text { Julia's 'pork pies' }\end{array}$ \\
\hline 7 August & $\begin{array}{l}\text { Gillard and Rudd 'meeting' } \\
\text { in Brisbane }\end{array}$ & & \\
\hline 8 August & $\begin{array}{l}\text { Coalition launch in } \\
\text { Brisbane }\end{array}$ & & $\begin{array}{l}\text { 'He's [Abbott] tough } \\
\text { and targeted but has } \\
\text { no new message', Paul } \\
\text { Kelly (The Australian, } 9 \\
\text { August 2010) }\end{array}$ \\
\hline 11 August & $\begin{array}{l}\text { Gillard/Keneally announce } \\
\text { Epping-Parramatta rail link }\end{array}$ & & \\
\hline 11 August & $\begin{array}{l}\text { Community forum in } \\
\text { western Sydney }\end{array}$ & & \\
\hline
\end{tabular}




\begin{tabular}{|c|c|c|c|}
\hline Date & Event & Comments & $\begin{array}{l}\text { Media coverage } \\
\text { highlights }\end{array}$ \\
\hline 12 August & $\begin{array}{l}\text { Gillard launches Tasmanian } \\
\text { broadband }\end{array}$ & & \\
\hline 15 August & 'Huge swing to Abbott' & $\begin{array}{l}\text { Galaxy poll in } 20 \\
\text { marginal seats }\end{array}$ & $\begin{array}{l}\text { Sunday Herald Sun (15 } \\
\text { August) }\end{array}$ \\
\hline 16 August & Labor launch in Brisbane & $\begin{array}{l}\text { Jobs, economy } \\
\text { and health } \\
\text { Thirtieth day of } \\
\text { campaign }\end{array}$ & \\
\hline 17 August & $\begin{array}{l}\text { Gillard's comment about } \\
\text { the republic }\end{array}$ & & \\
\hline 17 August & Abbott at the Press Club & $\begin{array}{l}\text { The monarchy } \\
\text { 'ongoing' } \\
\text { (response to } \\
\text { Gillard) }\end{array}$ & \\
\hline 18 August & $\begin{array}{l}\text { Second community forum, } \\
\text { Brisbane }\end{array}$ & & \\
\hline 19 August & Gillard at the Press Club & & \\
\hline 19-20 August & $\begin{array}{l}\text { Abbott's non-stop } \\
\text { campaign }\end{array}$ & $\begin{array}{l}3 A M \text { talkback } \\
\text { radio }\end{array}$ & \\
\hline 21 August & Polling day & & \\
\hline
\end{tabular}

For the first few days, the main policy and political issues attracting comment were whether a Coalition government would reintroduce WorkChoices - as in Abbott's famous 'dead, buried and cremated' comment on Melbourne radio 3AW; and the relations between the ALP and the Greens regarding preferencing arrangements. Gillard's first of three interviews on the 7.30 Report covered climate change, and the relations with the Greens. Bob Brown made his first major intervention by rather curiously suggesting (on Lateline) that he had no advice and that people were free to preference as they wish. It was Tony Abbott's interview with Neil Mitchell on Melbourne radio on 19 August declaring the end of WorkChoices (featuring a signed contract to that effect) that was to replay throughout the election campaign and into the 'politics' of the new Gillard Government (see, for example, The Age 2010c). The radio interview was photographed for the print and electronic media. ${ }^{2}$

The debate about debating — which would be a feature of the campaign — started, however, by focusing on the clash with a particularly popular commercial television show, MasterChef, and the debate time was shifted to $6.30 \mathrm{pm}$ to avoid a clash.

2 According to The Age (2010c): 'WorkChoices is the Coalition's zombie policy. It won't go away despite Opposition Leader Tony Abbott repeatedly declaring it "dead, buried and cremated" before August's federal election.' 
While the print media focused on the two major-party leaders, the other media utilised a range of party spokespeople. Notable were the ALP's Chris Bowen (Finance and Superannuation Minister and campaign spokesman), Bruce Hawker (ALP political consultant) and Paul Howes (Australian Workers' Union: AWU); and on the other side, Coalition spokesman Andrew Robb, Senators Eric Abetz and George Brandis and former Victorian Liberal Party President Michael Kroger. Paul Howes' colourful reference to Abbott's radio contract as reflective of 'a Newt Gingrich contract style campaign' was a case in point of his attacking style (Lateline, ABC TV, 20 July 2010). Chris Bowen's (in AFL terms: the 'smiling assassin') reference to Abbott as a 'WorkChoices addict' was equally biting (Lateline, ABC TV, 20 July 2010). From the other side of politics, Andrew Robb's comments were more measured if equally critical as he spoke of the need for cuts of $\$ 1.2$ billion from the Commonwealth bureaucracy. His comments were in tune with the first Liberal advertisement that under Labor there would be 'more waste, more debt, more taxes'; whereas the first advertisement from the Labor side (AWU) was colourful: an Addams Family spoof on the Coalition reintroducing WorkChoices.

Victoria became an issue a few days into the campaign; while Abbott had visited Melbourne twice in the first three to four days of the campaign, the Coalition had not established its campaign headquarters (normally in Melbourne) by 21 July. Andrew Robb was forced to defend this delay and to explain why candidates had not been preselected in a number of seats.

The media interest in State and regional questions firmed early with the focus on key marginal seats. ${ }^{3}$ Sky had started its analysis on day one of the campaign with an overview of the raft of key seats in New South Wales and particularly Queensland and the impact of the redistribution. The ABC picked up on key marginal seats with a detailed case-study approach, commencing in the ultramarginal Victorian seat of McEwen, with the retirement of the Liberal's Fran Bailey.

Back in Sydney, Julia Gillard's carefully crafted style moved into attack mode when, speaking at an education conference, she said 'Abbott can't be trusted' and launched National Trade Cadetships (Sky National News, 21 July 2010). That day, immigration was on the agenda for Gillard in a radio interview on 2UE, in which she was quizzed over the details of her immigration policy.

\footnotetext{
3 Lateline on 'marginal seats' (ABC TV, 20 July 2010). In McEwen (Vic.): MP Fran Bailey was retiring, and the seat was being contested by Rob Mitchell (Labor) and Cam Caine (Liberals); bushfires were a major concern, as well as the fact that 10000 people had moved to the area since 2007. There was a 32-vote margin in 2007-the narrowest in the country, with five recounts and a High Court challenge. In Dawson (Qld): the ALP MP was retiring, and Mike Barker, Mayor of Whitsundays, was standing for the ALP; the LNP candidate was Mackay councillor George Christensen.
} 
In Brisbane, Tony Abbott announced a school initiative tax rebate, in conjunction with Christopher Pyne, who presented himself as a father of four. Questions were subsequently raised by the media about the Coalition's focus upon the marital status of their leadership group - as implying some lack on Gillard's side.

Yet to appear on the 7.30 Report, Abbott, on 21 July, made an appearance on the popular live Melbourne TV show Hey Hey It's Saturday with Kylie Minoguean opportunity Julia Gillard had declined (Shepherd 2010).

Then on 22 July the campaign was suspended for a digger's funeral. Yet the involvement by Australia in the Afghan war attracted little discussion, apart from the Greens' wish to call a parliamentary debate on the subject.

Labor resumed its campaign on 23 July, in Brisbane, with the announcement of the new climate change policy of a citizens' assembly; the policy was prereleased for that day's media. It seemed a sign that Labor was grasping the nettle and producing a coordinated media campaign around an important policy-one that Gillard had indicated (on 24 June) was one of her priority issues.

Abbott meanwhile had travelled to Perth to keep an appointment at the Liberals' State Conference, and to proselytise about the evils of the mining tax. Having emphasised his credentials as a parent earlier in the campaign, he now chose to speak of the 'women in his life'. Deputy leader, Julie Bishop, followed up on this theme.

Perhaps this discussion of gender was in response to the morning's Nielsen poll showing a 54-46 gender gap among women favouring Gillard? These polls are normally previewed on the Friday-night edition of Lateline. Friday's Morgan Poll (Sky News 23 July 2010) also showed a gender gap. A Westpoll based on four marginal seats showed strong movement to the ALP; Sky News referred to the 'female vote', especially in Canning, with former State MP Alannah MacTiernan ahead and the sitting MHR, Sharyn Jackson, in Hasluck on 54:46 two-party preferred. The Today show (Channel Nine 2010) decided that Abbott might have a problem with women.

Whilst the gender gap was working in Gillard's favour at this stage of the campaign (see Stewart 2010), her new policy initiatives were, however, poorly received, and to commentators such as Michelle Grattan (2010) suggested a lack of policy capacity. The ill-fated climate change assembly policy was followed quickly (on 24 July in Brisbane) by another policy initiative: a $\$ 2000$ rebate for second-hand cars traded in for new cars-criticised almost immediately as a copy of the 'cash for clunkers' policy of US President Barack Obama. 
In the lead-up to the National Press Club debate scheduled for Sunday, 25 July, activist group GetUp!'s High Court challenge to the early roll closure- -based on Howard legislation that had not been amended by the ALP due to the numbers in the Senate - was launched. ${ }^{4}$ It had to await an actual challenge by late enrolees. The Press Club debate is the subject of another chapter in this volume (Chapter 7), so will be outlined only briefly (see also Gilbert 2010a). The Liberals won the coin toss and decided Julia Gillard would speak first (announced 24 July). There was little of substance in the debate. Julia Gillard announced $\$ 6.8$ billion to support retrenched workers. Tony Abbott announced his 'Action Contract' with the Australian people; mentioning gender, he argued that the Prime Minister is elected on 'ability, not gender'.

The Sky TV forum noted Julia Gillard arrived at between 3 and 4 pm and Tony Abbott at $4 \mathrm{pm}$. In its backgrounder, presenter Ashleigh Gillon commented on the stage-managed nature of Julia Gillard's campaign, with only one street walk (in Leichhardt in Sydney), conceding, however, that 'a lot of women' were going up to Julia. The Sky studio panel split, predictably on partisan lines. John Hewson said 'the debate was hers [Gillard's] to lose', and Bruce Hawker spoke of the good momentum achieved over the past five days.

The Sky panel gave the debate to Abbott; a lone dissenter from The Daily Telegraph said that Julia Gillard 'engaged and responded' and was the victor by a narrow margin. Gillon commented that it was stage-managed and dull. Tony Abbott was 'not convincing' on industrial relations, and his 'human side' was not on display.

The classic comment - that there was 'no knockout blow' - came from the Sky compere, Kieran Gilbert, and overall the panel thought Gillard should have been more attacking especially over Abbott's record as Health Minister. David Speers, who had hosted the actual debate, saw Julia Gillard as 'very polished' and 'more confident' than Abbott, who read his speech.

Over on Channel Nine's 60 Minutes, of the panel of Laurie Oakes, Helen McCabe (Editor, Australian Women's Weekly) and the famous worm, Oakes thought Abbott performed better. McCabe noted the gender gap of the worm: overall, the worm scored Julia Gillard 63 per cent and Tony Abbott 37 per cent. Sixty per cent of women preferred Julia Gillard and 61 per cent of men, and 39 per cent of men preferred Tony Abbott and 34 per cent of women.

The gender theme continued, but not in a positive way, when the next day (Monday, 26 July) Julia Gillard was in Tasmania (Bass) where questions regarding her spouse ('where was Tim?') overshadowed her health announcements of \$96 million for emergency doctors and nurses.

4 Closed Monday 8 pm, and change of address Thursday, 8 pm; writs issued on Monday, 19 July. 
Tony Abbott was in Brisbane (Petrie) with his wife, who runs an early childhood centre, and stated that the best way of boosting the population was children.

One new announcement was the restoration of tax indexation to the childcare rebate, and Abbott referred to the previous week's announcement of tax rebates for all educational expenses, noting the 'cost of living pressures' for 'struggling families'. He appeared on the 7.30 Report to be examined over his immigration policy, and could 'not specify exact cuts'. Host Kerry O'Brien said that the figures were trending down after the high levels of the Howard years. Abbott looked uncomfortable.

Questioning of Gillard about her marital status continued in Brisbane the next day when she announced a 'male-friendly' policy of more investment in suicide prevention, saying: 'We want to reach out to men.' Asked whether she was getting married, she replied: 'personal decisions are for personal reasons.' On the 7.30 Report (ABC TV, 27 July 2010) that evening, Bob Brown expressed 'disgust' at the personal attacks on Gillard, and the $A B C$ 's political reporter Heather Ewart claimed that voters were turned off by personal attacks and negative campaigning.

Tony Abbott, also in Queensland, campaigning in Dawson, returned to policy and announced suspension of marine protection legislation to 'open up jobs'.

The big news on 27 July was the 'leak story' by Laurie Oakes (Nine Network) and Peter Hartcher (Sydney Morning Herald) that Gillard opposed pension increases and the introduction of paid parental leave (see also Gilbert 2010b). Her initial response that day was to declare that Cabinet discussions were confidential. The next day in her home town of Adelaide, she called a press conference to deal with allegations of her opposing parental leave and pension increases in the Rudd Cabinet. She denied having opposed them: 'I'm denying that.' The claim was 'not credible', based on everything about her, in terms of ' $[w]$ ho I am, and what I have done'; she said her interest was in 'the cost'. The subsequent headlines and front pages in the tabloids were extraordinarily critical of Gillard, and The Daily Telegraph (29 July 2010) digitally altered her image to age it 25 years. In a subsequent Sky Agenda interview with Peter Hartcher, who broke the Gillard Cabinet story in the Sydney Morning Herald, David Speers, conducting the interview, said her response was 'impressive'.

Meanwhile, Tony Abbott had commenced his action-hero phase of the campaign and was interviewed discussing tax policy reform (that is, personal tax cuts and family cuts and indexation) while travelling on the Manly ferry in Sydney.

In an attempt to provide a balanced analysis of Cabinet and shadow Cabinet issues, Barnaby Joyce was interviewed on Sky over the original parental-leave policy announcement not being discussed in shadow Cabinet. 
There followed a few quiet days with 'low-key', 'low-cost' announcements on both sides (Lateline, ABC TV, 29 July 2010). ${ }^{5}$ Julia Gillard travelled to Perth and made a broadband announcement with Stephen Conroy. She was pictured - in television clips and in the print media-handpassing a football at Coolbinia Bombers junior Australian football club. The Today show (Channel Nine, 29 July 2010) picked up on 'Abbott's woman problem' as reflected in the gender gap in the polls, the perceptions of commentators and voices in the street.

Tony Abbott travelled to Adelaide (Sturt - Christopher Pyne's seat). There were front-page photos of Christopher Pyne and his family, including disabled children. There was an announcement on \$134 million for school students with a disability, and education vouchers. Bronwyn Bishop also attended. The weekend of 31 July and 1 August was disastrous for Labor and a triumph for the Coalition. The Nielsen poll, published in the weekend Sydney Morning Herald and The Age, was headlined as follows: 'Abbott takes the lead' (Sydney Morning Herald 2010) and 'Blow to Labor as Abbott surges' (The Age 2010). ${ }^{6}$

Both leaders campaigned across the country: Gillard was at home in Melbourne watching the Western Bulldogs (AFL) at Etihad Stadium; and Tony Abbott was in Darwin on board the HMAS Maitland remaining disciplined and announcing caring social policies including additional nursing-home beds, pet therapy in nursing homes, and free medical care to families of defence personnel. Then on Saturday night's $A B C$ News came the headline: 'Deputy PM sent former security guard to national security meetings when she was acting PM.' This was followed by mention of Kevin Rudd's illness and an interview with Thérèse Rein.

\section{Stage Three}

By August, the Labor campaign was in dire straits and attempts to gain media space for policy announcements were overshadowed by the number of embarrassing leaks and leak stories (Gilbert 2010b). For example, Gillard's attempt to launch Peter Garrett's campaign in Maroubra and hand over government coastal land to the community was overshadowed by an incredibly bizarre interview with Alexander Downer that dominated the Sunday tabloids. Witness The Sunday Telegraph's front-page story (1 August 2010) _ 'Libs: we used Rudd as a leaking double agent' - and the interview with Downer providing details. The Greens' launch that day was also overshadowed.

529 July: Julia Gillard in Melbourne, where she announced disability measures; Tony Abbott in Melbourne. 30 July: Julia Gillard in Perth, photographed handballing a football at Coolbinia Bombers junior football club while Tony Abbot was in Adelaide.

6 Nielsen poll: two-party preferred-Coalition 52 to ALP 48; and preferred prime minister, 49:41, with Gillard down 5 per cent and Abbott up 6 per cent. 
Monday's Newspoll showed Labor holding on better than in the Nielsen poll in terms of the two-party preferred vote, and Gillard redoubled her campaigning and her policy announcements. ${ }^{7}$ Her symbolic reaching out to the conservative Christian community was replayed on the evening news; when visiting a western Sydney school, she clearly was shown saying 'amen' at the school prayer. She also announced a greater role for principals and additional tax benefits for sixteen to eighteen-year-olds in school.

That evening - evidently based on the slipping polls - she offered Abbott a second debate (on the economy) the following Sunday (the day of the Coalition launch). Abbott declined. While Gillard's invitation was on Network Seven's Today Tonight, Abbott's decline was on Sky News. Jenny Macklin also appeared on Sky (Agenda) referring to herself as 'a mother, as well as an MP'.

The Coalition - having one theme of stopping waste, and so on, and another of no more WorkChoices - developed a third: the ALP's 'faceless men'. ${ }^{8}$

The next day, 2 August, saw the appearance of the 'real Julia'. This was based on an interview with the Herald Sun aboard her jet: 'I think it's time for me to make sure that the real Julia is well and truly on display...So I am going to step up and take personal charge of what we do in the campaign from this point' (Hudson 2010). Gillard and Swan subsequently travelled on the media bus from Sydney to Newcastle. She was the first leader since Paul Keating in 1996 to do this and it showed in the words of her Herald Sun interview she was 'go[ing] for it'.

Gillard's statement concerning a second debate was made on the press bus: 'I'd be happy to debate him [Abbott] on the economy on Sunday night...[I] would be happy to debate him on any night.' Abbott quickly responded to the debate challenge: 'The time for changing the rules has passed.' And infamously: 'No doesn't mean no when you are speaking to Julia; she said no repeatedly.'

The unfortunate choice of words was seized upon by female MPs - for example, Senator Sarah Hanson-Young (Greens) - and Tony replied: 'I'm not going to cop this vicious smear from the Labor Party.'

Tony Abbott was back in Brisbane - with daughter Louise-re-announcing paid parental leave (first introduced in March), with modifications that included starting in mid-2012 and a lower levy on business: 26 weeks at full pay up to $\$ 150000$ and the paperwork handled by government. According to Abbott, his was a better scheme than the government's of 18 weeks paid for by taxpayers.

7 Newspoll: two-party preferred, 50:50.

8 Tony Abbott in Cairns and Townsville offering more money for tourism, and referring to the ALP's 'faceless men'. 
The next day (4 August) Julia Gillard was also in Brisbane (and Cairns), where she announced more generous baby bonuses, including a $\$ 500$ cash bonus. Gillard continued to focus on jobs and families, renewed the challenge to Abbott to debate economic matters and reminded the nation that ' $[w]$ hen the GFC hit we had the better plan to support jobs'.

The Labor team's attempt to focus on its economic strengths was derailed again with Gillard's second interview on the 7.30 Report (3 August); host Kerry $\mathrm{O}^{\prime}$ Brien had invited both leaders to appear three times and that night was Julia's second interview. O'Brien said: 'Last week was a very bad week', then followed up with: 'Why didn't you call Kevin Rudd in hospital?' (Rudd was just home after three days in hospital for minor gall-bladder surgery.) The first part of the interview was on Labor's economic strengths, and the second part concerned the price of carbon.

Tony Abbott continued to campaign in Brisbane (Dickson). His message was directed towards retirees and he promised changes to the Commonwealth Seniors Health Card, incentives for business to hire older workers (aged fifty to sixty-five) to be paid after six months, and that he would remove the age bar on accessing superannuation. He was drawn to comment on the WA burqa case: ' 'It is a confronting type of attire.' Overall, he remained on message: 'End the waste, debt repaid, big taxes and boats [would be] stopped.'

This was the week that saw Labor lose 6 per cent in the Newspoll, and the 7.30 Report (ABC TV, 4 August 2010) interviewed electoral expert Antony Green on the likely electoral result. It was agreed that different swings would occur in different States and that pro-Labor swings likely in Victoria and South Australia might 'save the day' for the ALP. Green foresaw different swings within States and regions and cast doubt on there being a uniform swing. Kerry O'Brien commented that the 'Liberals have less money for direct mail'. Newspoll had more pronounced State swings than Nielsen.

Julia Gillard campaigned in Townsville (Leichhardt) on 5 August and then travelled to Sydney for a 'Mary McKillop' fundraising dinner, while Kevin Rudd announced at his first post-hospital press conference that he would campaign vigorously to '[s]top Abbott sliding into office'.

The 7.30 Report (ABC TV, 5 August 2010) invited Liberal Shadow Health Minister, Peter Dutton, to debate health policy; he refused and Health Minister, Nicola Roxon, outlined Labor's policy. That evening, Transport and Infrastructure

9 A woman in WA asked to wear a burqa in order to give evidence in a trial; this provoked community debate and was criticised by Tony Abbott and the WA Premier Colin Barnett. The judge subsequently ordered her to remove the burqa. 
Minister, Anthony Albanese, announced the eastern seaboard highway-'a commitment now to be built in the future'. Tony Abbott, in Sydney, said that the Coalition's health policy would spend 'more on doctors, less on bureaucrats'.

The next day (6 August) former party leaders entered the fray. John Howard was on the campaign trail in Sydney while in Melbourne Malcolm Fraser said the Coalition was 'not ready for government'. Former Labor leader Mark Latham entered the campaign as a journalist for Channel Nine's 60 Minutes.

Julia Gillard campaigned in Melbourne and lost her shoe on a building site (Herald Sun 2010). In response to questions from journalists regarding Kevin Rudd, she replied: 'we are chronic texters.' Tony Abbott was in Sydney attending a black-tie fundraising dinner with John Howard and would be at 'a mystery location tomorrow'.

On 6 August the High Court handed down its decision to support the GetUp! challenge to Howard legislation that closed the electoral rolls at $8 \mathrm{pm}$ on the day the writs were issued. The case was first heard on 4 August.

On 7 August, Julia Gillard was in Brisbane and 'appeared' at a face-to-face meeting with Kevin Rudd at the Brisbane Commonwealth Offices (Maher 2010). A strangely choreographed affair, the meeting was captured with no sound. Campaigning at the Brisbane Show (the EKKA), she was interviewed by Mark Latham and photos show his aggressive body language (see AAP 2010). Gillard announced a 'pensioner pledge' where pensioners could earn up to $\$ 6500$ without affecting their pension. Tony Abbott was also in Brisbane and met with the President of Nauru (returning from the South Pacific Forum in Fiji); this was arranged by the Shadow Immigration Minister, Scott Morrison, and Deputy Opposition Leader, Julie Bishop.

The Nielsen poll was a front-page feature in the Fairfax broadsheets: 'Labor trailing Coalition 2PP 48:52' (The Age 2010b; Sydney Morning Herald 2010b). The articles made mention of the Coalition winning in 1998 with 49 per cent of the two-party preferred vote. (For a detailed analysis of the polls, see Chapter 6 in this volume.) The Orgill Report on the Building the Education Revolution (BER) scheme was released, and was not entirely negative, with some positives mentioned.

On 8 August, Julia Gillard was in Darwin speaking about her School Chaplains' Scheme, and Kevin Rudd was campaigning in Brisbane where he held a press conference that was captured on the evening TV news programs. Jenny Macklin promised to recognise Indigenous people in the Constitution (ABC National News, 8 August 2010); Channel Nine apologised to Gillard over Mark Latham (AAP 2010). 
This day also saw the Coalition launch in Brisbane. Tony Abbott promised a debt-reduction committee, and the main themes were continued: pay back the debt, cut the waste, secure the borders. He spoke of a contract with Australia and provided a detailed time line - for example, day one: phone the President of Nauru. Julie Bishop focused on Labor's 'soap opera' with leadership issues. The Nationals' Warren Truss - picking up on Julia Gillard's recent comment that she texted Kevin Rudd-mentioned Julia had to 'text her ex' to have someone to dance with (see Australian Agenda, Sky TV, 8 August 2010).

On Monday, 9 August, Julia Gillard was in Perth - calling for performance pay for school principals, moves towards a standard national curriculum and the baccalaureate. She agreed to a Wednesday-night forum in Sydney. She was well received on the $A B C$ 's $Q \& A$ program.

Tony Abbott remained in Brisbane. He visited the Brisbane Show and a home with faulty insulation. The 7.30 Report announced that Tony Abbott was to have his second interview on Wednesday, 11 August.

Wayne Swan and Joe Hockey debated the economy at the National Press Club. Hockey was questioned about the Coalition's costings, which were to be submitted that day. Peter Costello hit back at the use of his anti-Abbott comment in an ALP advertisement.

Julia Gillard travelled back to the east from Perth for events in Adelaide and Geelong on 10 August. In Adelaide, she announced the findings of the MurrayDarling Report, which recommended funding extra water for the river system, and extra funds for professionals to undergo teacher training. She visited her old school in Adelaide. In Geelong (Corangamite), she announced the GeelongWinchelsea duplication (with Anthony Albanese) and Belmont super clinic (with Darren Cheeseman).

Tony Abbott travelled south to Sydney for his second 7.30 Report interview. He appeared to muff his answer on information technology (IT) and then referred to himself as not a 'tech head' and regrouped to define the Coalition's IT policy as a 'national, not nationalised system'; it was to be based on wireless technology. In general, he left the broadband debate to his communications and finance shadow ministers. Kevin Rudd was appointed to the UN Secretary-General's Panel on Sustainability.

On Wednesday, 11 August, Abbott and Gillard swapped places. Gillard was in Sydney, where, beside NSW Premier, Kristina Keneally, and Infrastructure Minister, Anthony Albanese, she announced the Parramatta to Epping rail link, with the money to flow from 2018. 
Tony Abbott was at the mouth of the River Murray, with Barnaby Joyce, announcing a government water buy-back scheme to enable the river to flow again. He also provided a welfare update with the family allowance contingent upon compulsory health checks for four-year-olds, and $\$ 6000$ for workers relocating to rural and regional Australia.

Wednesday evening saw the Rooty Hill RSL Club civic debate. Julia Gillard spoke first and encountered a number of 'hostile' questions, especially regarding Kevin Rudd's dispatch. This was according to The Daily Telegraph's Malcolm Farr, who was part of the Sky studio panel. Tony Abbott then spoke and stayed on the floor rather than sitting on a stool on the stage as Gillard had done. He introduced himself as a 'fellow Sydneysider'. Farr referred to Gillard's 'headmistressy high chair' but also noted a 'hubris' moment for Abbott's comment 'when I'm Prime Minister'.

Earlier in the day, the National Press Club hosted a 'health policy' debate between Nicola Roxon and Peter Dutton. Key policy differences emerged: the ALP promised hospital takeovers by the Commonwealth (negotiated by Rudd before the election), with local boards, GP super clinics, and block funding for diabetes; and the Coalition promised \$36 billion for community-controlled hospitals, mental health funding and after-hours rebates under the rubric of 'cutting the bureaucrats'. Aged care and Indigenous housing were, however, omitted.

On 12 August, Julia Gillard was in northern Tasmania to launch the Tasmanian broadband rollout, with Communications Minister, Stephen Conroy. Tony Abbott remained in western Sydney. At the Penrith RSL Club, he promised a welfare boost for veterans and an 'office of due diligence', and critiqued the ALP's broadband scheme as a 'technological rabbit out of the hat'. Mark Latham dropped in on Tony Abbott at the RSL.

The evening news noted that the Coalition's expenditure was not yet in for Treasury costing. This set the scene for the Wayne Swan and Joe Hockey interview on the 7.30 Report. On 13 August, Julia Gillard was in Sydney to make education announcements regarding \$350 million for individual bonuses for trades training and $\$ 5500$ per apprentice. She referred to the Coalition's 'dog ate my homework excuse' to avoid costings.

Tony Abbott was in Melbourne with Christopher Pyne for education policy announcements and visited a Christian college in the seat of Deakin and schools in Colac and Geelong (Corangamite). He announced the Coalition's 'new technology fund' and awards for high-achieving teachers; he promised to axe the Government's computers in schools program. No prior details were released of Abbott's Victorian trip. 
On 14 August, Julia Gillard campaigned on the NSW North Coast (Page) near Ballina. She announced a carbon-credit scheme for farmers and for traditional landowners, to be sold to polluters. She was wearing riding boots ( $A B C$ News Victoria, 15 August 2010; The Age, 15 August 2010). She headed back to Melbourne for campaigning that evening and the next day. Both Nielsen and Newspoll showed Labor 'on the nose' in Queensland and New South Wales.

Tony Abbott was in Perth where he flipped the coin at a football match and spoke at the head office of Barmino, a mining contractor. The ABC News Victoria headline was Abbott '[p]ledges more help for miners'.

On Sunday, 15 August, Julia Gillard was in the northern suburbs of Melbourne (Diamond Creek) calling on Tony Abbott to debate the economy. She was flying to Brisbane that evening for the ALP policy launch. Tony Abbott was on the NSW Central Coast.

That evening Sky News's Agenda featured an interview with Nick Xenophon regarding a possible hung parliament. It also discussed the three IndependentsRob Oakeshott, Tony Windsor and Bob Katter-who were all ex-Nationals, stating that the Coalition was campaigning against Windsor.

On Monday, 16 August, Julia Gillard was in Brisbane for the official ALP launch, in the early afternoon. It was a low-key 'bread and butter' launch. Health, jobs and the economy were major themes. Sky News referred to the 'display of unity'. Tony Abbott toured five marginal seats in western Sydney and also the Australian Defence Force Academy (ADFA) in Canberra. In Sydney's west, he campaigned on an anti-mining tax platform, and against gangs.

There was also the final 7.30 Report interview with Julia Gillard; Kerry O'Brien referred to the 'last-minute launch...on the thirtieth day of the campaign'. He questioned Gillard over why there were no Cabinet discussions over the EppingParramatta rail link; she replied that 'there are no formal Cabinet meetings during election campaigns. We are in caretaker mode.' Tony Abbott agreed to debate the economy (PM, Sky TV, 16 August 2010).

On 17 August, Julia Gillard campaigned in north and central Queensland, visiting Townsville, Mackay and Emerald, and agreed to another town-hallstyle forum to be held in Brisbane on Wednesday, 18 August. She was flying to Perth that evening so was unable to debate the economy 'then and there'. She made a brief reference to a republic 'when we see the monarch change'. Tony Abbott spoke at the Press Club later that day and responded to Gillard's comment by referring to the monarchy as 'on-going'. 
Joe Hockey was interviewed by David Speers on Sky regarding when the economy would be back in surplus, and he apparently contradicted comments by Queensland Senator George Brandis who had earlier stated that the budget would not be back in surplus for 10 years.

On community forum day-18 August-Julia Gillard commenced by campaigning in Perth (Hasluck), and then travelled back to Brisbane for the forum at the Brisbane Broncos Rugby League Club. She would be flying out again only half an hour after the forum.

Tony Abbott spoke first and received a cooler reception than he had in Sydney. (Abbott had earlier been in Gladstone-Flynn.) Julia Gillard appeared more relaxed and comfortable; she received questions about same-sex marriage.

On 19 August, Julia Gillard spoke at the National Press Club and announced paternity leave for 'new dads' ${ }^{10}$ She would be travelling to the NSW Central Coast (Patterson) that evening.

Earlier that morning (19 August), Tony Abbott had started out at the Brisbane markets at dawn, was interviewed for the Today show, and promised an allnight 'campaigning marathon'. He visited four Brisbane marginal seats and then travelled to Sydney (Bennelong). He was not planning to sleep before polling day (36 hours).

Channel Seven News noted Labor was ahead on national polling, 52 to 48, but 'at risk', and showed a copy of Labor's 'secret polling' in which it was in 'danger of losing seats in Queensland and New South Wales'. The news also showed the 'polligraph' 2:1 in favour of Julia Gillard (audience watching the Brisbane forum in Melbourne). It noted that Gillard received support from women and Abbott from men. Voters were unhappy at the dumping of Rudd.

The 7.30 Report had Hugh McKay referring to the 'ratification poll'. Antony Green noted that the polling only 'made sense' by States. While all polls were showing Labor ahead nationally, it was barely ahead in New South Wales and Queensland.

Queensland was vulnerable as there were 10 Labor seats with margins of 5 per cent or less. The Liberal National Party (LNP) was a new party. In New South Wales, there was a 'complicated' redistribution. According to Kerry $\mathrm{O}^{\prime}$ Brien, there were also likely to be different patterns within States: Victoria and South Australia 'may save Labor'. Possible gains were Sturt and Boothby

10 A Current Affair reported on the Press Club speech. 
(South Australia) and McEwen and Corangamite (Victoria). The prospect of a hung parliament was raised: 'Greens have said they would support a Labor Government', noted Antony Green.

Lateline's Tony Jones interrogated Labor's Chris Bowen: 'Why has Labor leaked its polling?' Bowen sidestepped, saying it would be the closest result since 1961. Andrew Robb claimed Labor was 'rolling out the leak' to condition expectations. It was, however, 'not far off the Liberal internal polling and the other published polls'.

The Newspoll of 50:50 (Tuesday and Wednesday) suggested a momentum shift and that 'every day is critical' (Tony Jones, Lateline 19 August 2010). The discussion shifted to the 'Charter of Budget Honesty', introduced in 1998: this was the first time the Coalition had not followed procedures. The aim was to allow the Opposition to have costings advice provided free.

By 20 August, there had been 35 days of non-stop campaigning. Julia Gillard campaigned on the NSW Central Coast and finished up in Sydney in Bennelong with Maxine McKew where she opened the Top Ryde shopping centre. She warned of the 'risks' of WorkChoices and that 'every vote is about the choice of Prime Minister'. In her interview with David Speers, she stated that the '[c] hoice is between me and Mr Abbott. We are investing, building, training.'

Tony Abbott's 'campaign blitz' commenced at the early morning markets, and, in his interview on A Current Affair, he said the 'real risk' was a 'really bad government'; and he denied that he would reintroduce WorkChoices. The polls showed the Coalition expecting to pick up six to 10 seats and Labor expecting it to be 'a lot closer than that'.

The final TV interviews on the $\mathrm{ABC}$ and commercial stations saw the distillation of the main themes by the two leaders: Gillard (ABC) saw 'a real choice, a tough contest...I do have a positive plan for jobs, health, hospitals, broadband'. Abbott (ABC) argued Australia would '[f]ix problems by changing the government'. In his final Channel Nine interview (20 August), he was more low key, commenting on how 'hard' he had campaigned in his efforts to hold the government to account and to present a 'clear alternative'. Table 2.3 outlines the post-election saga. 
Julia 2010: The caretaker election

Table 2.3 Post-Election Events

\begin{tabular}{|l|l|l|}
\hline \multicolumn{2}{|c|}{ Date } & \multicolumn{2}{c|}{ Comment } \\
\hline 1 September & Greens back ALP & $\begin{array}{l}\text { Media commentary that Bandt had } \\
\text { previously agreed to support the ALP; } \\
\text { see Tally Room, 23 August 2010 }\end{array}$ \\
\hline 2 September & Andrew Wilkie to support ALP & $\begin{array}{l}\text { Climate change committee at Cabinet } \\
\text { level, dental care, high-speed rail, } \\
\text { parliamentary debate on Afghanistan } \\
\text { and political donation laws }\end{array}$ \\
\hline 3 September & Bob Katter's 20-point plan & \\
\hline 7 September & Katter supports Coalition & \\
\hline 7 September & $\begin{array}{l}\text { Tony Windsor and Rob } \\
\text { Oakeshott support ALP }\end{array}$ & \\
\hline 7 September & $\begin{array}{l}\text { Julia Gillard meets the Governor- } \\
\text { General }\end{array}$ & \\
\hline 11 September & $\begin{array}{l}\text { Gillard announces ministerial } \\
\text { reshuffle }\end{array}$ & \\
\hline 14 September & $\begin{array}{l}\text { Gillard, followed by the ministry, } \\
\text { is sworn in }\end{array}$ & \\
\hline
\end{tabular}

\section{Conclusion}

Opposition Leader, Tony Abbott, referred to the experience as the 'longest election'; commentator Hugh McKay spoke of the campaign as a process of 'ratification' (7.30 Report, ABC TV, 19 August); SBS's Karen Middleton framed the campaign as a 'referendum on Julia Gillard' (SBS News, 20 August 2010); still others raised serious questions as to the competency of the ALP's strategy and tactics. The subsequent experience of minority government has left the leading media commentators somewhat puzzled and searching for a script. A few commentators - mainly in the tabloid media (for example, Simon Kearney from the Herald Sun and the Sun-Herald's Mia Freedman)-latched on to gender as a defining feature; whereas the broadsheets, as typified by The Age (see Michelle Grattan's work), had decided Australia was in a post-gender paradigm, and gender was no longer relevant.

Other longer-term and deeper explanations provide important context. As in 2007, David Marr's (2010) perceptive and biting analysis of the personality and style of the incumbent Prime Minister (John Howard in 2007 and Kevin Rudd in 2010) was picked up by political commentators. The economy, while featured in Julia Gillard's early speeches, did not gain sustained coverage, although Andrew Scott (2010) reminds us that the GFC saw governments tumble internationally, replaced with hung parliaments and minority governments. 


\section{References}

Australian Associated Press (AAP). 2010. 'Nine boss apologises after Mark Latham's Julia Gillard interview "lacked proper respect"'. AAP, 8 August, viewed 20 January 2011, <http://www.news.com.au/features/federalelection/nine-boss-apologies-after-mark-lathams-interview-lacked properrespect/>

Channel Nine. 2010. 'Do women hate Tony Abbott?'. Today, 29 July, <http:// video.au.msn.com/watch/video/do-women-hate-tony-abbott/xik8ljz>

Gilbert, Kieran. 2010a. 'The debate'. Kieran Gilbert Blog, viewed 21 January 2011, <http://www.skynews.com.au/blogs/blog.aspx?Blog=2\&Post=1115>

Gilbert, Kieran. 2010b. 'The Coalition wins week two'. Kieran Gilbert Blog, viewed 21 January 2011, <http://www.skynews.com.au/blogs/blog. asp $\mathrm{x}$ ? Blog $=2 \&$ Post $=1125>$

Gillard, Julia. 2010a. Edited transcript of Julia Gillard's acceptance speech, 24 June, <http://www.theaustralian.com.au.news/edited-transcript-of-juliagillards-acceptance-speech/story-e6frg6nb-122588-3840584>

Gillard, Julia. 2010b. Speech to the Lowy Institute, 6 July, Sydney.

Gillard, Julia. 2010c. Full transcript of Prime Minister Julia Gillard's address to the National Press Club, 15 July, Canberra, < tonyserve.wcanberraorddpress. com $/ 2010 \ldots /$ full-transcript-of-prime-ministerjulia-gillards-adress-to-thenational-press-club-canberra/>

Gillard, Julia. 2010d. Opening statement at press conference, 17 July, Parliament House, Canberra, <http://www.alp.org/federal-government/news/speechjulia-gillard-opening-statement-at-press/>

Grattan, Michelle. 2010. 'PM rocked by Labor leaks amid bitter divisions'. The Age, 28 July, 1.

Herald Sun. 2010. 'Gillard loses her footing'. Herald Sun, 6 August, viewed 24 February 2011, <http://video.dailytelegraph.com.au/1560359121/Gillardloses-her-footing $>$

Hudson, Philip. 2010. 'Julia Gillard vows to take control of her election campaign'. Herald Sun, 2 August, viewed 20 January 2011, <http://www. heraldsun.com.au/news/special-reports/julia-gillard-vows-to-take-controlof-her-election-campaign $>$ 
Julia 2010: The caretaker election

Kelly, Paul. 2010. 'He's tough and targeted but has no new message'. The Australian, 9 August, 1.

Maher, Sid. 2010. 'Julia Gillard and Kevin Rudd meet, but won't campaign together'. The Australian, 7 August, viewed 24 February 2011, <http:// www.theaustralian.com.au/national-affairs/julia-gillard-meets-kevin-ruddbut-won't-campaign-together/>

Marr, David. 2010. Power Trip: The political journey of Kevin Rudd. Quarterly Essay 38 (June). Melbourne: Black Inc.

Scott, Andrew. 2010. Paper presented to Deakin University Workshop on the Politics of Economic Crisis, 12 November, Melbourne.

Shepherd, Tony. 2010. 'Hey Hey Saturday crowd boos Tony Abbott'. The Daily Telegraph, 22 July.

Simms, Marian. 2011. 'Westminster norms and caretaker conventions: Australian and New Zealand transition debates'. In Paul t'Hart and John Uhr (eds), How Power Changes Hands: Transition and succession in government. Basingstoke, UK: Palgrave Macmillan.

Stewart, Cameron. 2010. 'Julia Gillard hot but women cool on Tony Abbott'. The Australian, 22 July.

Sydney Morning Herald. 2010a. 'Abbott takes the lead'. Sydney Morning Herald, 31 July - 1 August.

Sydney Morning Herald. 2010b. 'Labor trailing Coalition 2PP 48:52'. Sydney Morning Herald, 7 August.

The Age. 2010a. 'Blow to Labor as Abbott surges'. The Age, 31 July - 1 August.

The Age. 2010b. 'Labor trailing Coalition 2PP 48:52'. The Age, 7 August.

The Age. 2010c. 'Coalition must redefine itself on IR' [Editorial]. The Age, 7 October.

The Sunday Telegraph. 2010. 'Libs: we used Rudd as a leaking double agent'. The Sunday Telegraph, 1 August. 